Thermolability of Soybean Allergen Gly m bd 30K:

\title{
Report of a Case of Anaphylaxis
}

Ojeda $\mathrm{P}^{1}$, Pineda $\mathrm{F}^{2}$, Mourelle $\mathrm{R}^{1}$, Rubio $\mathrm{G}^{1}$, Yago A ${ }^{1}$, Baquero $\mathrm{D}^{1}$, Ojeda $\mathrm{I}^{1}$

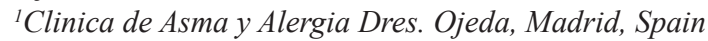

${ }^{2}$ Diater Laboratories, Madrid, Spain

J Investig Allergol Clin Immunol 2018; Vol. 28(5): 360-362

doi: 10.18176/jiaci.0291

Key words: Soybean. Food allergy. Gly m bd30K. Thermolability. Anaphylaxis.

Palabras clave: Soja. Alergia alimentaria. Gly m bd30K. Termolabilidad. Anafilaxia.

Soybean is a legume from the oilseed family that is widely consumed by humans and animals owing to its high content in proteins, carbohydrates, and fiber [1].

A Spanish study carried out in children revealed a positive result in $45 \%-85 \%$ of skin prick tests and specific $\mathrm{IgE}>0.7 \mathrm{kU} / \mathrm{L}$ against soybean, although fewer than $5 \%$ presented symptoms after consumption [2]. Heat treatment, fermentation, and high-pressure processing may affect the allergenic potential of soy products [3].

We report the case of a 38-year-old man who experienced skin itching, facial angioedema, progressive dyspnea, low blood pressure, and loss of consciousness requiring hospitalization at an intensive care unit for 24 hours. The symptoms appeared 5-10 minutes after eating a premade white chocolate drink with almonds during the summer. At the time, he was being treated with finasteride, ibuprofen $600 \mathrm{mg}$ (for joint pain, last dose 3-4 hours before onset of symptoms), omeprazole, and hemorrhoid cream. He reported no previous effort and had eaten steak and pasta for lunch (both tolerated after the episode). Tryptase levels during the episode were $4.2 \mu \mathrm{g} / \mathrm{dL}$.

Previous allergy studies reported negative skin prick test results. Specific IgE against respiratory and food allergens (ISAC Microarray, Thermo Fisher) was negative to the whole panel, and challenge tests with ibuprofen and omeprazole were also negative. The patient had been advised to avoid nuts before coming to our clinic and tolerated chocolate without symptoms.

Skin prick tests were repeated with Dermatophagoides pteronyssinus, Alternaria species, dog and cat dander, grass pollen, olive tree pollen, Taraxacum species, milk, egg, wheat, gluten, gliadin, cashew, lupin bean, white fish, blue fish, shrimp, peanut, walnut, sunflower seed, peach LTP, latex, Anisakis species, cocoa, and sesame). Once again, the results were negative.

As the results of tests with the beverage components had all been negative and chocolate was unlikely to be the cause of the anaphylactic reaction, a challenge test was scheduled with the same white chocolate he had consumed 
the day he experienced the reaction, previously prepared in $200 \mathrm{~mL}$ of temperate milk $\left(30-35^{\circ} \mathrm{C}\right)$. He experienced a mild burning sensation on the forearm after $1 \mathrm{~mL}$ and then on the chest after $5 \mathrm{~mL}$. General pruritus and facial and cervical hives developed 10-15 minutes after $25 \mathrm{~mL}$. He was treated with $80 \mathrm{mg}$ of methylprednisolone and $5 \mathrm{mg}$ of dexchlorpheniramine. The reaction progressed to general urticaria, intense dizziness, and dyspnea requiring intramuscular adrenaline $0.3 \mathrm{~mL}$ and new doses of methylprednisolone and dexchlorpheniramine.

New skin prick and prick-prick tests were performed with the ingredients of the white chocolate - soy sauce, soybean seeds, soy vegetable oil, commercial soybean, corn, chocolate $(1 \mathrm{~g} / \mathrm{mL})$, raw almond, roasted almond, hazelnut, and walnutand yielded positive results for soy sauce and chocolate only. In addition, the patient confirmed good tolerance to foods containing soy vegetable oil (he had subsequently eaten mayonnaise containing this oil [25\%]).

SDS-PAGE and immunoblotting were performed with water-soluble and fat-soluble fractions of walnut, hazelnut, soy, glutenin, gliadin, and chocolate.

Intense binding of specific IgE to a protein from the soy fat-soluble fraction (approximately $30 \mathrm{kDa}$ ) was discernible. This band was recognized in both the fat-soluble and watersoluble soy extracts, although the binding was subtler with the water-soluble fraction and nearly imperceptible with the chocolate extract (Figure, A). Although less intense, IgE binding to other soy proteins could correspond to Gly $\mathrm{m} 4$ (PR-10 protein, 17-kDa and Gly $\mathrm{m} 6$ [glycinin, 11S globulin]) (Figure, A) based on comparison with the binding proteins described in the Allergome database. The patient's serum was tested against soybean extract treated at $95^{\circ} \mathrm{C}$ (Figure, B) and $200^{\circ} \mathrm{C}$ (Figure, C). The intensity of IgE binding was decreased at $95^{\circ} \mathrm{C}$ and had completely disappeared at $200^{\circ} \mathrm{C}$.
Gly $\mathrm{m}$ bd $30 \mathrm{~K}$ is the major allergen of soybean. It is a $32-\mathrm{kDa}$ protein corresponding to the soybean vacuolar protein (p34) and has been identified as a constituent of the seed's oil storage organelles or oil bodies [4].

In the case described, we observed serum specific $\operatorname{IgE}$ binding to an approximately $30-\mathrm{kDa}$ protein from both the fat-soluble fraction and the water-soluble fraction, although this was less intense in the water-soluble fraction. This fraction could correspond to Gly m bd 30K. However, the patient reported no symptoms after eating food containing $25 \%$ soy vegetable oil.

The last production phase for soy vegetable oil consists of a deodorization process in which all the organic compounds are eliminated [5]. This process consists of low-pressure vapor distillation at a high temperature (around $180-200^{\circ} \mathrm{C}$ ). Soybean sauce is produced by fermentation of beans, reaching temperatures of around $95^{\circ} \mathrm{C}-100^{\circ} \mathrm{C}[6,7]$.

The immunological study was repeated after heating extracts to $95^{\circ} \mathrm{C}$ and $200^{\circ} \mathrm{C}$ (Figure, B and C). At $95^{\circ} \mathrm{C}$, the water-soluble fraction completely disappeared and clearly diminished in the fat-soluble fraction. At $200^{\circ} \mathrm{C}$, IgE recognition for both fractions disappeared.

These in vitro experiments confirmed hypersensitivity to the principal soy allergen Gly $\mathrm{m}$ bd $30 \mathrm{~K}$, which degrades at temperatures above $200^{\circ} \mathrm{C}$. Consequently, the patient was able to eat food with soy vegetable oil but reacted to food containing soybean. The results also explain the negative skin prick test results with soybean commercial extract (since the fat-soluble fraction is removed during the production process), with soy vegetable oil (where the allergen is denaturalized), and with the positive soy sauce and the chocolate drink containing soybean (which in turn contains water and fat-soluble fractions and is not submitted to temperatures as high as $200^{\circ} \mathrm{C}$ during the production process). A possible explanation of why the
A

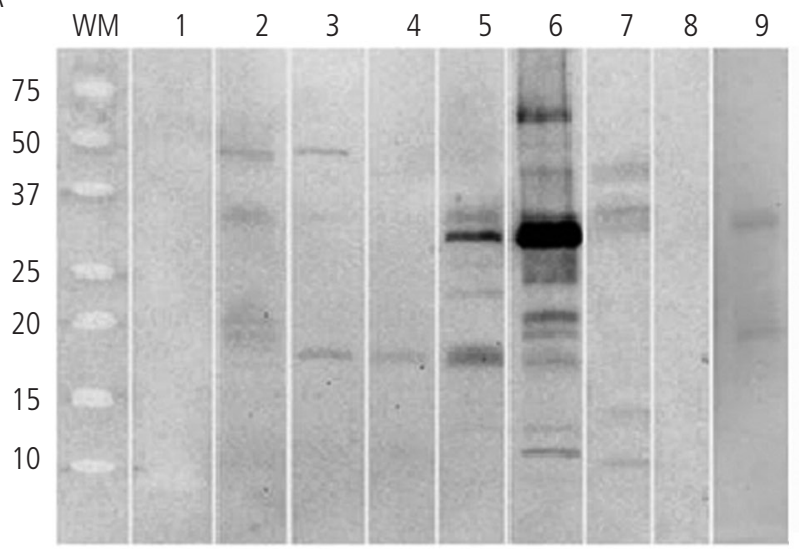

B

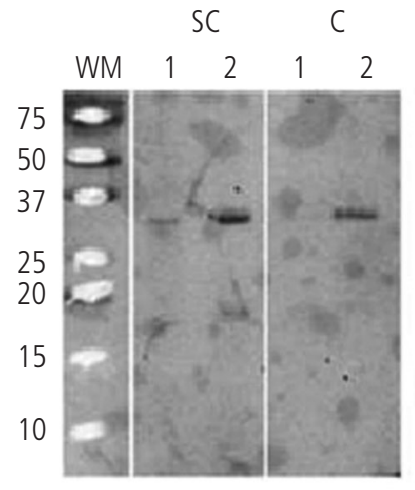

C

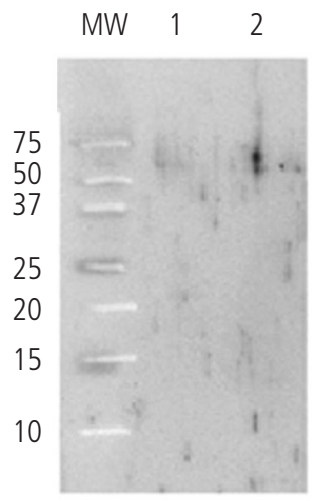

Figure. A, Immunoblotting assay with the patient's serum and possible allergens. Lane 1, water-soluble walnut fraction; lane 2, fat-soluble walnut fraction; lane 3, water-soluble hazelnut fraction; lane 4, fat-soluble hazelnut fraction; lane 5, water-soluble soybean fraction; lane 6, fat-soluble soybean fraction; lane 7, glutenin; lane 8, gliadin; lane 9, chocolate. B, Recognition of the 32-kDa protein from fat-soluble soybean fraction. Lane 1, watersoluble soybean fraction; lane 2, fat-soluble soybean fraction; SC, extracts without previous heating; C, extracts heated up to $95^{\circ} \mathrm{C}$. C, Immunoblotting assay with soy bean (water and fat-soluble) extracts heated at $200^{\circ} \mathrm{C}$. Lane 1, water-soluble soybean fraction; lane 2, fat-soluble soybean fraction. MW indicates molecular weight. 
prick-prick test with soybean seeds was negative could be that soybean seeds do not release the allergen contained inside the oil bodies with this technique.

In 2016, Asero et al [8] reported a case of anaphylaxis caused by ingestion of foods containing soybean with positive skin prick test results to soybean. However, the authors were unable to detect specific IgE against 3 of the main soybean allergens: rBet v 1 (homologous to Gly $\mathrm{m} 4$ ), rGly $\mathrm{m}$ 5, and rGly $\mathrm{m} 6$.

We therefore present the case of a severe anaphylactic reaction caused by the principal allergen of soybean, Gly $\mathrm{m} 30$, as an ingredient of a premade chocolate drink. To our knowledge, this is the first time this protein has been shown to denaturalize at high temperatures $\left(200^{\circ} \mathrm{C}\right)$. This should be taken in account when approaching patients with soybean allergy, since they may tolerate foods containing soy vegetable oil.

\section{Funding}

The authors declare that no funding was received for the present study.

\section{Conflicts of Interest}

The authors received technical assistance from Diater Laboratories for the in vitro allergy study.

Fernando Pineda is currently employed by Diater Laboratories.

\section{Previous Presentation}

Data from this article were presented in poster format at the SEAIC 2015 international symposium, which took place in Seville, Spain, October 22-24, 2017.

\section{References}

1. OECD/FAO (2007), OECD-FAO Agricultural Outlook 2007, OECD Publishing, Paris: 2007. 67-78

2. Sánchez JJ, Fernández-Caldas E, Ibáñez MD, Martínez M. Reactividad cruzada de las legumbres. J Allergol Immunopathol. 2003;31(3):151-61.

3. Besler M, Steinhart $H$, Paschke A. Stability of food allergens and allergenicity of processed foods. J Chromatogr B Biomed Sci Appl. 2001 May 25;756(1-2):207-28.

4. Ogawa T, Tsuji H, Bando N, Kitamura K, Zhu YL, Hirano $H$, Nishikawa K. Identification of the soybean allergenic

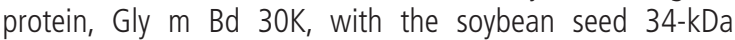
oil-body-associated protein. Biosci Biotechnol Biochem. 1993; 57(6):1030-3.

5. Food and Agriculture Organization of the United Nations and the World Health Organization. Fats and oils in human nutrition: Report of a joint expert consultation. Rome 19-26 October 1993;

6. Magishi N, Yuikawa N, Kobayashi M, Taniuchi S. Degradation and removal of soybean allergen in Japanese soy sauce. Molecular Medicine Reports. 2017;16:2264-8.

7. Cabanillas B, Cuadrado C, Rodriguez J, Dieguez MC, Crespo JF, Novak N. Boiling and Pressure Cooking Impact on Ig E
Reactivity of Soybean Allergens. Int Arch Allergy Immunol. 2018;175(1-2):36-43.

8. Asero R, Mistrello G, Amato S, Villalta D. Unusual allergy to soy appeared in adult age. Eur Ann Allergy Clin Immunol. 2016 May;48(3):94-6.

Manuscript received December 4, 2017; accepted for publication July 4, 2018.

Rocío Mourelle Aguado Clinica de Asma y Alergia Dres. Ojeda, c/Oquendo 23 28006 Madrid, Spain E-mail: rocio.mourelle@clinicaojeda.es 